A $\underset{\text { publications }}{\mathrm{C}} \mathrm{Rec. \text {Nat.Prod.12:6(2018)569-581 }}$

records of natural products

\title{
Chemical Characterization of 64 Propolis Samples from Hakkari, Turkey
}

\author{
Nesrin Ecem Bayram ${ }^{\oplus *}$, Kadriye Sorkun ${ }^{\oplus 2}$, Gül Cevahir $\ddot{\text { Öz }}{ }^{\oplus 3}$, \\ Bekir Salih $^{\oplus 4}$ and Gülaçtı Topçu ${ }^{\oplus *}$
}

\author{
${ }^{1}$ Department of Food Processing, Aydintepe Vocational College, Bayburt University, 69500- \\ Bayburt,Türkiye \\ ${ }^{2}$ Department of Biology, Faculty of Science, Hacettepe University, 06800- Ankara, Türkiye \\ ${ }^{3}$ Department of Biology, Faculty of Science, Istanbul University, 34134-Istanbul, Türkiye \\ ${ }^{4}$ Department of Chemistry, Faculty of Science, Hacettepe University, 06800- Ankara, Türkiye \\ ${ }^{5}$ Department of Pharmacognosy \& Phytochemistry, Faculty of Pharmacy, Bezmialem Vakıf University, \\ 34093-Istanbul, Türkiye
}

(Received December 30, 2016; Revised June 07, 2018; Accepted June 08, 2018)

\begin{abstract}
Propolis is a resinous substance produced by honey bees from various plants they visit. Sixty-four propolis samples were collected from different localities of four districts (Merkez, Yüksekova, Şemdinli, and Çukurca) in Hakkari territory. Ethanol extracts of the propolis samples were prepared, and their chemical contents were determined by gas chromatography-mass spectroscopy (GC-MS). Flavonoids were generally found in a high concentration in Şemdinli samples of Turkey. Twenty-seven coumarins were identified in the 28 propolis samples among studied 64 ones. Except suberosin, the coumarins were never reported before in any propolis sample with Turkish origin. The propolis samples belonging to Yüksekova were found to be richer in coumarins than the others, and the most richest one among the Yüksekova apiaries, was found to be Akocak sample (Y2) with 41.99\% total yield, followed by Akçalı sample (Y5) (30.86\%). This is a first comprehensive and original report about the chemical profile of propolis samples from Hakkari. The propolis samples from Hakkari exhibited a chemical content rich in flavonoids including coumarins and furocoumarins.
\end{abstract}

Keywords: Chemical analysis; coumarin; flavonoid; Hakkari; propolis. (C) 2018 ACG Publications. All rights reserved.

\section{Introduction}

Since more than 125 million years, bees are still one of the most important and hard worker species of the nature. This success may be related to the chemistry and fields pertaining to the application of specific bee products such as honey, pollen, propolis, beeswax, venom, and royal jelly [1]. Among these products, propolis is a nontoxic natural substance collected by honey bees (Apis mellifera) from the cracks in the bark of trees and leaf buds [2]. The bees mix these resins with

\footnotetext{
* Corresponding authors: E-Mail: gulacti_topcu@yahoo.com (G.Topçu); ecem.nesrin@gmail.com (N. Ecem)
} 
substances derived from pollen and different types of enzymes [3]. Propolis is gradually gaining more attention recently because of its antioxidant, antibacterial, antifungal, antiviral, anticancer, and immunostimulating activities [4].

Natural products have played an important role in drug discovery [5]. The use of propolis dates back to B.C. 300 [6]. This product was discovered by the Greeks for the first time and used as a natural antibiotic. Propolis, because of its antiputrefactive property, was used in the mummification of dead bodies by ancient Egyptians and as a mouth disinfectant by Romans and Greeks. In addition, it was used as an antipyretic material by Incas and as a lotion for treatment of various illnesses in Georgia [7]. As propolis increases appetite and decreases lung problems, it was used in tuberculosis treatment in Soviet clinics during World War II [8]. Use of products containing propolis have resulted in extensive dermal contact, however it is now increasingly being used as a dietary supplement. In fact, there is a substantive database on the biological activity and toxicity of propolis which was reported in detail by Burdock in a review article including some clinical reports of propolis allergy [2], since reports of allergic reactions are not uncommon, propolis should be yet considered relatively non-toxic.

Nowadays, propolis is still used as a natural medicament, particularly in Brazil and Eastern European countries [9]. Propolis was introduced to the global market in capsule, pastille, toothpaste, and cream forms $[2,6,10]$. At the same time, it is being consumed as a healthy drink in various Asian, European, and American countries [11]. However, propolis which are rich in furanocoumarins should be consumed carefully, due to their some properties, such as irreversible CYP3A4 inhibitor, and organic anionic transporter and $\mathrm{P}$ glikoprotein $(\mathrm{ABC})$ inhibitor. Therefore, their chemical analysis results should be documented with their detail content and allergens information for the consumers.

Propolis has a very diverse composition and is potentially a source of biologically active compounds [12]. The chemical composition of propolis depends on the plant variety, geographical properties, and climatic conditions of the region where collected from [9]. Until now, more than 500 compounds were identified in the chemical composition of propolis [13]. The fact that a variety of chemicals in the chemical composition of a propolis sample depends on its collection region which prevents the exact standardization of propolis. For this reason, the information about the usage of propolis is generally a suggestion. The quality and quantity of the constituents and nonexistence of contamination in propolis are important points for standardization $[14,1]$.

In this study, the chemical compositions of the propolis samples obtained from apiaries of Hakkari territory, which is located at the most south-East Anatolian region, in the border of Iran and Iraq, were determined. The similarities and differences between the samples were evaluated and important groups of compounds were identified. Thus, a chemical profile of the Hakkari propolis, particularly Yüksekova samples exhibited a remarkable differentiation with the presence of coumarins at moderate-high percentages from the investigated propolis of other regions of Turkey.

\section{Materials and Methods}

\subsection{Propolis Samples}

Raw propolis samples were obtained from apiaries at 64 different locations belonging to four districts (Merkez, Yüksekova, Şemdinli, and Çukurca) of Hakkari within two years 2011-2012. Thirteen samples were collected from Merkez, nineteen samples were collected from Yüksekova, thirty samples were collected from Şemdinli, and two samples were collected from Çukurca. The locations are listed in Table 1. Raw propolis samples were collected with traps placed on the top of the beehives.

\subsection{Extraction and Sample Preparation}

Propolis samples were frozen in the fridge $\left(-18{ }^{\circ} \mathrm{C}\right)$, crushed into pieces, and dissolved in $96 \%$ ethanol $(1: 3, \mathrm{w} / \mathrm{v})$. This mixture was kept in the incubator at $30^{\circ} \mathrm{C}$ for four weeks in a tightly closed 
nontransparent bottle. After four weeks, the supernatant was filtered twice with Whatman No. 4 and No.1 filter paper, respectively. The filtered solution was diluted in 1:10 ratio (w/v) with ethanol $(96 \%)$ and evaporated to complete dryness. About $5 \mathrm{mg}$ of the dry propolis was mixed with $75 \mu \mathrm{L}$ of dry pyridine and $50 \mu \mathrm{L}$ bis (trimethylsilyl) trifluoroacetamide (BSTFA) and heated at $80^{\circ} \mathrm{C}$ for 20 min, and then, the final supernatant was analyzed by gas chromatography-mass spectroscopy (GC-MS).

\subsection{Gas Chromatography-Mass Spectroscopy (GC-MS) Analysis}

Samples were analyzed using a GC 6890N from Agilent (Palo Alto, CA, USA) coupled with mass detector (MS5973, Agilent) equipped with a DB-5 MS capillary column $(30 \mathrm{~m} \times 0.25 \mathrm{~mm}$ and $0.25 \mu \mathrm{m}$ of film thickness). The column oven temperature was initially maintained at $50^{\circ} \mathrm{C}$ for $1 \mathrm{~min}$ and then programmed to rise to $150^{\circ} \mathrm{C}$ at $10^{\circ} \mathrm{C} / \mathrm{min}$ and maintained for $2 \mathrm{~min}$. Finally, the temperature was increased to $280^{\circ} \mathrm{C}$ at $20^{\circ} \mathrm{C} / \mathrm{min}$ and maintained at $280^{\circ} \mathrm{C}$ for $30 \mathrm{~min}$. Helium was used as the carrier gas at a flow rate of $0.7 \mathrm{~mL} / \mathrm{min}$.

\subsection{Identification of Compounds}

The compounds in the propolis samples were identified by using the Wiley and NIST libraries available in the data acquisition system of the GC-MS apparatus if the comparison scores obtained were higher than 95\%. Otherwise, fragmentation signals of the compounds in mass spectra were evaluated, and the compounds were identified. The percentage reports of the compounds in the samples were reported. This was the standard way to quantify the many organic compounds in the propolis samples. In this case, the relative error could not be higher than 5\% [15].

\section{Results and Discussion}

The chemical composition of 64 propolis samples supplied from Hakkari territory was investigated. The yields percentages of the dry propolis extracts were found extending between $2.50 \%$ to $27.22 \%$ which are presented in Table 1. However, the two samples; one from Şemdinli (Altınsu location) and the other Yüksekova (Bulaklı location) were obtained extremely with low yield $(0,22$ and $0.56 \%$, respectively). In total, more than 250 individual compounds were determined in propolis samples. Because of the variability of plant sources belonging about 30 distinct families, the chemical composition of each propolis was found to be highly variable [16]. Compounds such as flavonoids, phenolics, essential oils, aromatic aldehydes, alcohols, and terpenes are among the compounds determined in different propolis samples [10]. Aliphatic, carboxylic, and cinnamic acids and their esters as well as hydrocarbons, coumarins, flavonoids, and terpenes (monoterpenes, sesquiterpenes, and diterpenes) were determined in propolis samples examined in this study (see supporting information Table S1).

It is well known that flavonoid content and concentration will affect the biological activity of propolis [17]. In the present study, flavonoids were found almost in all detected Hakkari samples, and the highest percentage of flavonoids was determined in a sample S19 (34.46\%) obtained from Şemdinli district. Flavonoids (apigenin, chrysin, galangin, gengkwanin, kaempferol, naringenin, pinocembrin, pinostrobin chalcone, sulfuretin, and tectochrysin) were identified as the main components in 22 of 50 samples. These compounds were determined in the propolis samples collected from Merkez (in 10 of 13 samples), Yüksekova (in 15 of 19 samples), Şemdinli (in 23 of 30 samples), and Çukurca (in 2 of 2 samples) districts within the ranging 1.61\%-22.86\%, $0.28 \%-30.22 \%, 2.14 \%-$ $34.46 \%, 10.14 \%-14.83 \%$, respectively. Our results are in agreement with those found by different researchers [15], namely as flavonoids consisting of flavones, flavans, chalcones, aurones (pinocembrin, pinostrobin, isalpinin, pinobanksin, quercetin, naringenin, galangine, and chrysin) as main constituents of Hakkari propolis samples. 
Table 1. Geographical origins and yield of dry extract of propolis samples

\begin{tabular}{|c|c|c|c|c|c|c|c|}
\hline Sample & District & Locality & Yield (\%) & Sample & District & Locality & Yield (\%) \\
\hline M1 & Merkez & Durankaya & 27.22 & S1 & Şemdinli & Korgan & 22.67 \\
\hline M2 & Merkez & Kamışlı & 10.16 & S2 & Şemdinli & Çatalca-Soğuk Su & 8.00 \\
\hline M3 & Merkez & Geçitli & 16.22 & S3 & Şemdinli & Aşağı Kayalar & 2.50 \\
\hline M4 & Merkez & Pinarca & 18.89 & S4 & Şemdinli & Aşağı Kayalar & 17.96 \\
\hline M5 & Merkez & Kırıkdağ & 6.22 & S5 & Şemdinli & Aşağı Kayalar & 20.67 \\
\hline M6 & Merkez & Kaval & 5.33 & S6 & Şemdinli & Yukarı Tuğlu & 11.33 \\
\hline M7 & Merkez & Cevizdibi & 23.11 & S7 & Şemdinli & Öveç- Karaağaç & 10.00 \\
\hline M8 & Merkez & Elmacik & 7.47 & S8 & Şemdinli & Yukarı Tuğlu & 11.67 \\
\hline M9 & Merkez & Işık & 8.5 & S9 & Şemdinli & Alan-Derecik & 8.67 \\
\hline M10 & Merkez & Uğurlu & 11.16 & S10 & Şemdinli & Günyazı-Hazne & 21.58 \\
\hline M11 & Merkez & Ceylanlı & 3.10 & S11 & Şemdinli & Alan & 5.56 \\
\hline M12 & Merkez & Yapraklı & 8.89 & S12 & Şemdinli & Altınsu & 0.22 \\
\hline M13 & Merkez & Geçitli & 3.57 & S13 & Şemdinli & Günyazı & 3.29 \\
\hline Y1 & Yüksekova & Akçalı & 5.00 & S14 & Şemdinli & Günyazı-Tanyolu & 6.83 \\
\hline Y2 & Yüksekova & Akocak & 18.8 & S15 & Şemdinli & Alan & 12.90 \\
\hline Y3 & Yüksekova & Bulaklı & 0.56 & S16 & Şemdinli & Çatalca & 7.00 \\
\hline Y4 & Yüksekova & Büyükçiftlik & 5.19 & S17 & Şemdinli & Günyazı & 12.83 \\
\hline Y5 & Yüksekova & Akocak & 11.3 & S18 & Şemdinli & Așağı Kayalar & 17.98 \\
\hline Y6 & Yüksekova & Salkımlı & 6.00 & S19 & Şemdinli & Tekeli & 18.84 \\
\hline Y7 & Yüksekova & Tuğlu & 8.70 & S20 & Şemdinli & Çatalca & 9.63 \\
\hline Y8 & Yüksekova & Karlı-Beşpınar & 7.50 & S21 & Şemdinli & Çatalca-Erdemli & 10.66 \\
\hline Y9 & Yüksekova & Su üstü & 5.28 & S22 & Şemdinli & Yukarı Kayalar & 3.51 \\
\hline Y10 & Yüksekova & Dağlıca & 9.05 & $\mathbf{S 2 3}$ & Şemdinli & Tekeli & 8.53 \\
\hline Y11 & Yüksekova & Yekmal & 8.00 & S24 & Şemdinli & Tekeli-Balıklı & 11.75 \\
\hline Y12 & Yüksekova & Akpınar & 9.17 & S25 & Şemdinli & Kayalar-Mağaraönü & 14.44 \\
\hline Y13 & Yüksekova & Onbaşılar-Çamdalı & 10.10 & S26 & Şemdinli & Aktütün & 13.16 \\
\hline Y14 & Yüksekova & Onbaşılar & 8.93 & S27 & Şemdinli & Öveç-Derya & 11.99 \\
\hline Y15 & Yüksekova & Akocak & 8.80 & S28 & Şemdinli & Uğuraçan & 13.34 \\
\hline Y16 & Yüksekova & Tuğlu & 4.50 & S29 & Şemdinli & Beyyurdu & 17.90 \\
\hline Y17 & Yüksekova & Kısıklı & 11.50 & S30 & Şemdinli & Bozyamaç & 16.53 \\
\hline Y18 & Yüksekova & Bataklık & 7.33 & C1 & Çukurca & Narlı & 6.32 \\
\hline Y19 & Yüksekova & Esendere & 7.89 & C2 & Çukurca & Çı̆̆gl & 8.33 \\
\hline
\end{tabular}


In the present study, coumarins were also detected in varying percentages, particularly obtained with high percentages in Yüksekova apiaries, with the highest percentage in Akocak sample (Y2), followed by Akçalı sample (Y5) (30.86\%). As it is known coumarins are also classified as a subclass of flavonoids. 27 Coumarins were identified in the 28 propolis samples among studied 64 ones. Similarly, Fernandes-Silva et al. [18] found flavanoids as major constituents of the samples from Minas Gerais, Brazil. Pinostrobin chalcone and pinocembrin were determined in most of the propolis samples.

Pinostrobin chalcone was found in 8 samples of Merkez (M1, M3, M4, M5, M6, M7, M11, and M13), 15 samples of Yüksekova (Y1, Y3, Y4, Y5, Y6, Y8, Y9, Y10, Y13, Y14, Y15, Y16, Y17, Y18, and Y19), 21 samples of Şemdinli (S1, S2, S3, S6, S7, S8, S10, S14, S17, S18, S19, S21, S22, S23, S24, S25, S26, S27, S28, S29, and S30), and one sample of Çukurca (C2) in different amounts. The highest concentration was determined in M3 sample as $11.30 \%$. Pinostrobin chalcone was also determined in the propolis of many other regions [19, 20,21], and its cytotoxic activity was shown against cancer cells [22].

Pinocembrin, which has activities such as antimicrobial [23], anti-inflammatory [24], antimutagenic [25], antioxidant [26], local anesthetic activities [10], was determined in M1, M3, M5, M6, M7, M10, M11, M12, Y1, Y3, Y4, Y6, Y8, Y10, Y14, Y15, Y16, Y17, Y18, Y19, S1, S2, S3, S6, S7, S8, S10, S16, S17, S18, S19, S20, S21, S22, S23, S24, S25, S26, S27, S28, S29, S30, C1, and C2 samples. The highest concentration for pinocembrin was determined in S19 (9.49\%) sample. Similarly, this compound was determined in other propolis samples from Turkey $[16,27]$ and Iran [28].

The flavonoid contents of propolis samples were similar to those of Algerian [29], American [30] and Mediterranean regions [31]. Popova et al. [32] determined that Pinus nigra and Populus euphratica Oliv. as the main botanical sources of Turkish propolis and marked the flavonoids pinocembrin, galangin, chrysin, kaempferol and phenolics phenethyl caffeate and benzyl ferulate as its major compounds [33]. Our results indicate that the propolis samples, in which the flavonoids were identified as the main component, showed a similar character to the poplar type propolis character. Furthermore, it has been determined that the propolis samples collected from Şemdinli have higher flavonoid content than the other propolis samples in general (see supporting information Table S2).

Coumarins, which are a wide class of flavonoids, play an important role in the defense mechanism of plants and have many useful biological effects on human health [34]. In this study, coumarins were determined in M3, M4, M7, M11, M13, Y2, Y3, Y4, Y5, Y7, Y9, Y13, Y14, Y16, Y17, Y19, S10, S12, S20, S21, S22, S23, S24, S25, S26, S27, S28, and S29 samples (Table 3). Among them, five propolis samples Y2, Y5, S28, Y13 and Y9 contain coumarins at high percentages; $41.99 \%, 30.86 \%, 25.65 \%, 12.48 \%, 12.30 \%$, respectively as their main components. The highest coumarin content sample, detected in Yuksekova, Akocak (Y2) consists of 8 coumarins, only two of them formed $39.72 \%$ of total percentage (compound $\mathbf{1 9}$ with $24.76 \%$ and compound $\mathbf{2 1}$ with 14.96 $\%) .14$ of total 27 coumarins identified have furanocoumarin structure, and except one of them, suberosin, all coumarins have been determined for the first time in Turkish propolis. However, suberosin was isolated before from Iranian propolis [35].

Except suberosin (16), the following 26 compounds were identified for the first time in propolis samples; angelicin (1), bergapten (2), bergaptol (3), columbianetin (4), decursin (5), isogeijerin (6), jatamansin (7), lomatin (8), methoxsalen (9), oroselone (10), osthole (11), oxypeucedanin (12), prangenin (13), psoralen (14), seselin (15), xanthotoxol (17), 4-hydroxymellein (18), 2-(1-(2-methylcrotonoyloxy)-1-methylethyl)-8-oxo-1,2-dihydrofurano[2,3-H]2H-chromene (19), norpterphyllin III (20), 2,2-dimethyl-6-oxo-2,3,6,6a-tetrahydropyrano[3,2-f]chromen-3-yl, 3-methyl2-butenoate (21), 2,2-dimethyl-pyrano-(3,2-c)(1)benzopyran-5-one (22), isoangenomalin (23), oxypeucedanin hydrate (24), isooxypeucedanin (25), 6-(2,3-dihydroxy-3-methylbutyl)-7methoxycoumarin (26), 7-ethoxyprocecene (27) (Table 2 and Figure 1).

Coumarins are a large group of secondary metabolites that are distributed in Apiaceae, Rutaceae, Asteraceae and Fabaceae [36], and many plants, particularly belonging to the Apiaceae family are rich in coumarins and furanocoumarins [37]. In a study on the botanical origins of the Hakkari propolis samples, Bayram (2015) [38] reported that 71 plant taxa belonging to 34 families 
were determined to be present at different ratios in the propolis samples and the pollens of the plants belonging to the families of Apiaceae (2.7\%-35\%), Asteraceae (3.4\%-35.4\%) and Fabaceae (12\%$66 \%$ ). It has been reported that coumarins angelicin [39,40], bergapten [39,41,42], bergaptol $[43,44]$, columbianetin [43], decursin [45], jatamansin [46], lomatin [47,48] methoxsalen [49], oroselone [50], osthole [51], oxypeucedanin [52,53,54], prangenin [55], psoralen [40,43], seselin [56], suberosin [57,58], xanthotoxol [59,60], 2-isopropenyl-2,3-dihydrofuro[3,2-g]chromen-7-one [61], 3-methyl-but2-enoic acid, 2,2-dimethyl-8-oxo-3,4-dihydro-2H,8H-pyrano[3,2-g]chromen-3-yl ester [62], and 4-(3methyl-2-oxobutoxy)-7H-furo[3,2-g][1]benzopyran-7-one (isooxypeucedanin) [63] are found in the chemical composition of different plants belonging to the Apiaceae family. Similarly, psoralen, angelicin [64], bergapten [65], and seselin [66] have been reported to be present in the Fabaceae family plants.

On the other hand, it has been reported that compounds osthole [67], isogeijerin [67], seselin [68,42], 6-(2,3-dihydroxy-3-methylbutyl)-7- methoxycoumarin [69] are found in plants of Rutaceae family. However, according to the Tubives (Turkish Plants Data Service) [70] data, the plant belonging to the Rutaceae family in the Hakkari flora was not identified. This clearly shows that there are still unspecified plant taxa visited by honeybees in the Hakkari region, and probably belonging to different plant taxa located in Hakkari, except the plants belonging to the Rutaceae family. In our study, the ratio of flavonoids was found to be low in the propolis samples in which coumarins were the main component, which indicates that these propolis samples do not exhibit typical poplar propolis character. These results support that propolis also uses other plant sources rather than poplar. No information is available in the literature on herbal sources of compounds 18, 19, 20, 21, 22, 24, 27 mentioned in Table 2, which is a question for future research. The most important result of the present study for the next step, is to bring a necessity for the investigation of coagulant/anticoagulant profile of those coumarins detected in the propolis samples for their useability, safely. Sure, there are some previous studies on some of them to investigate such activities.

Hydrocarbons are another group of compound determined in propolis samples. Any specific activity of hydrocarbons in propolis was not reported before [71]. Negri et al. [72] stated that beeswax hydrocarbon distribution was widely used in taxonomy for botanic science but that no relation can be established between hydrocarbon profiles and geographical closeness for propolis. These compounds are thought to be originated from bee metabolism. [73]. In our study, hydrocarbons were identified as the main component of 20 propolis samples. Hydrocarbons were determined in all samples except M9, Y12 and S13 (see supporting information Table S3). It was noticeable that highest hydrocarbon carrying sample (S4) did not bear flavonoids. Moreover, in addition to the hydrocarbons, the compounds belonging to the aliphatic acids and their esters were found to be quite high $(31.33 \%)$ in S4 sample (see supporting information Table S4).

As the carboxylic acids and their esters, they were not determined in 24 of 64 samples while they detected in minor ratios in 40 samples (see supporting information Table S5). The amounts of these compounds in propolis samples were different from each other. They were identified in highest ratio in S16 sample (6.21\%).

The aliphatic acids and their esters were detected in all samples except M10, M12 and Y11. They were determined in Merkez, Yüksekova, Şemdinli and Çukurca district samples at ratios of $0 \%$ $13.77 \%, 0 \%-15.01 \%, 0.21 \%-32.05 \%, 8.11 \%-8.76 \%$, respectively. In addition, in the chemical content of M9 and S13 have been only identified aliphatic acids and their esters. On the other hand, in 57 of 64 samples, ethyl oleate was determined at considerably high ratios. Similarly, this compound was determined in other propolis samples of Turkey [3, 76, 77]. Determination of ethyl oleate in different ratios in many propolis samples (57 samples) suggests that this compound may be a marker compound for the Hakkari region or even Turkey propolis. Ethyl oleate has been reported to be a major ester of queen bees [78]. This supports that this compound, which is detected in the chemical content of propolis, is originated from bee metabolism. In an earlier study, this compound has been reported to contribute to the efficacy of propolis against Leishmania infantum and Leishmania tropica [79]. 
Table 2. Coumarins in propolis samples (composition \%)

\begin{tabular}{|c|c|c|c|c|c|c|c|c|c|c|c|c|c|c|c|c|c|c|c|c|c|c|c|c|c|c|c|c|}
\hline Comp. & M3 & M4 & M7 & M11 & M13 & Y2 & Y3 & Y4 & Y5 & Y7 & Y9 & Y13 & Y14 & Y16 & Y17 & Y19 & S10 & S12 & S20 & S21 & S22 & $\mathbf{S 2 3}$ & S24 & S25 & S26 & S27 & S28 & S29 \\
\hline 1 & - & - & 0.35 & 0.15 & 0.13 & 0.11 & - & - & - & - & 0.65 & 0.84 & 1.03 & - & - & - & 0.3 & - & 0.29 & - & - & - & 0.18 & 0.45 & 0.09 & - & 0.76 & 0.15 \\
\hline 2 & - & - & - & - & - & - & - & - & 0.12 & - & - & - & - & - & - & - & - & - & - & - & - & - & - & - & 0.17 & - & - & - \\
\hline 3 & - & 4.23 & - & - & - & - & - & - & 0.81 & 1.5 & - & 0.11 & - & - & - & - & - & - & - & - & - & - & 0.91 & - & - & - & 0.74 & - \\
\hline 4 & - & - & - & - & - & - & - & - & - & - & - & 0.95 & 0.39 & - & - & - & - & - & - & - & - & - & - & - & - & - & 0.48 & - \\
\hline 5 & - & - & - & - & - & - & - & - & 10.32 & - & - & - & - & - & - & - & - & - & - & - & - & - & - & - & - & - & - & - \\
\hline 6 & - & - & - & - & - & - & - & - & - & - & - & - & - & - & - & - & - & - & - & - & - & - & - & - & 0.75 & - & - & - \\
\hline 7 & - & - & 1.91 & 0.52 & - & - & - & - & - & - & - & - & - & - & - & 0.86 & - & - & 1.55 & - & - & - & - & - & - & - & 12.82 & - \\
\hline 8 & - & - & - & - & - & - & - & - & - & - & - & - & - & - & - & - & - & - & - & - & - & - & - & - & 0.4 & - & - & - \\
\hline 9 & - & - & - & - & - & - & - & - & - & - & - & - & - & - & - & - & - & - & - & - & - & - & - & - & 0.1 & - & - & - \\
\hline 10 & - & - & - & - & - & 0.04 & - & - & - & - & - & - & - & - & - & - & - & - & - & - & - & - & - & - & - & 0.09 & - & - \\
\hline 11 & - & - & - & - & - & 0.19 & - & - & 4.29 & 0.45 & - & - & - & - & 1.12 & - & - & - & - & - & - & - & - & - & 1.41 & - & - & - \\
\hline 12 & - & - & - & - & - & - & - & - & - & - & - & - & - & - & - & - & - & - & - & - & 0.74 & - & 1.77 & - & - & - & - & - \\
\hline 13 & - & - & - & - & - & - & - & - & - & - & - & - & - & - & - & - & - & - & - & 0.58 & - & 0.3 & 2.12 & - & - & - & - & - \\
\hline 14 & - & - & - & - & - & 0.33 & - & - & - & - & - & - & - & - & - & - & - & - & - & - & - & - & - & - & - & - & - & - \\
\hline 15 & - & - & - & - & - & - & - & - & 0.19 & - & - & - & - & - & - & - & - & - & - & - & - & - & - & - & - & - & - & - \\
\hline 16 & - & - & 1.47 & - & - & - & - & - & - & 1.23 & - & - & - & - & - & - & - & 3.1 & - & 0.36 & - & - & 1.15 & - & 0.42 & - & - & - \\
\hline 17 & - & - & - & - & - & - & - & - & - & 3.67 & - & - & - & - & - & - & - & - & - & 0.15 & - & - & 0.38 & - & - & - & - & - \\
\hline 18 & 0.24 & - & - & - & - & - & - & - & - & - & - & - & - & - & - & - & - & - & - & - & - & - & - & - & - & - & - & - \\
\hline 19 & - & 2.26 & - & - & - & 24.76 & 3.37 & 0.89 & - & - & 11.65 & 9.11 & 5.29 & - & - & - & - & - & - & - & - & - & - & - & - & - & 10.85 & - \\
\hline 20 & - & - & - & - & - & - & - & - & - & - & - & - & - & - & - & - & - & - & 0.29 & - & - & - & - & - & - & - & - & - \\
\hline 21 & - & - & - & - & - & 14.96 & - & - & - & - & - & - & - & - & - & - & - & - & - & - & - & - & - & 4.10 & - & - & - & - \\
\hline 22 & - & - & - & - & - & 1.60 & - & - & 15.13 & - & - & - & - & - & - & - & - & - & - & - & - & - & - & - & - & - & - & - \\
\hline 23 & - & - & - & - & - & - & - & - & - & - & - & - & - & - & - & - & - & - & - & - & - & - & - & - & 0.78 & - & - & - \\
\hline 24 & - & - & - & - & - & - & - & - & - & - & - & 1.47 & - & - & - & - & - & - & - & - & 7.17 & - & - & - & - & - & - & - \\
\hline 25 & - & - & - & - & - & - & - & - & - & - & - & - & - & - & - & - & - & - & - & 0.61 & 0.97 & - & 1.65 & - & 0.83 & - & - & - \\
\hline 26 & - & - & - & - & - & - & - & - & - & - & - & - & - & - & - & - & - & - & - & - & - & - & - & - & 1.12 & - & - & - \\
\hline 27 & - & - & - & - & - & - & - & - & - & - & - & - & - & - & 2.18 & - & - & - & - & - & - & - & 2.57 & - & - & - & - & - \\
\hline
\end{tabular}


<smiles>O=c1ccc2ccc3occc3c2o1</smiles>

1<smiles>CC(C)=CC(=O)O[C@H]1Cc2cc3ccc(=O)oc3cc2OC1(C)C</smiles>

5<smiles>COc1c2occc2cc2ccc(=O)oc12</smiles>

9<smiles>CC1(C)O[C@@H]1COc1c2occc2cc2ccc(=O)oc12</smiles>

13<smiles>COc1c2ccoc2cc2oc(=O)ccc12</smiles>

2<smiles>O=c1ccc2c(O)c3ccoc3cc2o1</smiles>

3<smiles>CC(O)C1Cc2c(ccc3ccc(=O)oc23)O1</smiles>

4<smiles>C/C=C/C(=O)O[C@H]1Cc2c(ccc3ccc(=O)oc23)OC1(C)C</smiles><smiles>CC1(C)Oc2ccc3ccc(=O)oc3c2C[C@H]1O</smiles>

6

7<smiles>CC1(C)OC1COc1c2ccoc2cc2oc(=O)ccc12</smiles>

12<smiles>O=c1ccc2cc3ccoc3cc2o1</smiles>

14<smiles>CC1(C)C=Cc2c(ccc3ccc(=O)oc23)O1</smiles>

15<smiles>COc1cc2oc(=O)ccc2cc1CC=C(C)C</smiles>

16<smiles>O=c1ccc2cc3ccoc3c(O)c2o1</smiles>

17<smiles>CC1OC(=O)c2c(O)cccc2C1O</smiles>

18<smiles>CC=C(C)C(=O)OC(C)(C)C1Cc2c(ccc3ccc(=O)oc23)O1</smiles>

19<smiles>CC1(C)CCc2c(c3ccccc3oc2=O)O1</smiles>

20<smiles>CC(C)=CC(=O)OC1OC2=CC(=O)C3OC=CC=C3C2=CC1(C)C</smiles>

21<smiles>CC1(C)C=Cc2c(c3ccccc3oc2=O)O1</smiles>

22<smiles>C=C(C)C1Cc2cc3ccc(=O)oc3cc2O1</smiles><smiles>CC(C)(O)C(O)COc1c2ccoc2cc2oc(=O)ccc12</smiles>

24<smiles>CC(C)C(=O)COc1c2ccoc2cc2oc(=O)ccc12</smiles>

25<smiles>COc1cc2oc(=O)ccc2cc1CC(O)C(C)(C)O</smiles>

26<smiles>CCOc1cc2c(cc1OC)OC(C)(C)C=C2</smiles>

27

Figure 1. Structures of the identified coumarins detected in Hakkari propolis samples of this study 
Cinnamic acids and their esters are pharmacologically active constituents against bacteria [80]. Cinnamic acids and their esters which have an important role in activity of propolis especially with their antioxidant properties were found in minor ratios $(0.07 \%-2.18 \%)$ in 23 samples out of 64 (see supporting information Table S6).

Although volatiles only represent $10 \%$ of the propolis components, they account for the spesific resinous odor and contribute to the pharmacological activities of propolis. Some of monoterpenes, diterpenes and sesquiterpenes are proven to have a broad spectrum of pharmacological properties in propolis [13]. In our study, monoterpenes, diterpenes and sesquiterpenes were found in highest ratios in M5 (34.29\%), M12 (1.44\%) and Y3 (13.87\%), respectively (see supporting information Table S7, S8, S9). On the other hand, while the monoterpenes were detected in the highest ratio in M5, flavonoids were detected in very low amounts. Also, sesquiterpenes was detected in different quantities in 43 propolis samples and they were determined to be the main component of Y3, S11 and S20 samples. The terpenes were determined in the studies carried out by Şahinler and Kaftanoğlu [81], Temiz et al. [82] and Silici and Kutluca [83]. A monoterpene $\alpha$-pinene was found to be predominant in M4 and M8 samples. Although these samples had quite high monoterpene content and a very low flavonoid content likewise to the sample M5. $\alpha$-Pinene was also detected in Turkish propolis in the previous studies [81]. This compound has been reported to have a significant inhibitory effect on bacteria and contributes to the antimicrobial activity of propolis. [84]. Therefore, it can be said that M4 and M8 samples containing $\alpha$-pinene probably have high antimicrobial activity.

Although propolis samples of Hakkari located in south Eastern Anatolian region of Turkey show similarities with other propolis samples of Turkey, they also have important differences in terms of chemical content and plant source. As a result of chemical analyses of 64 propolis samples by GC-MS, it was determined that detected samples contain compounds in different ratios. Propolis samples of Şemdinli can be considered to be more valuable as they include high ratio of flavonoids which have an important role in propolis activity. On the other hand, the most important botanical sources of propolis are poplars, birches, willows, elms, pine trees, oaks, linden, cherry, apple and other trees [85,86]. There are several reports that the plant source of Turkish propolis is poplar, in general [83]. However, we have determined that some propolis samples have different chemical content from the poplar-type propolis. These results show that in Hakkari region, bees use other plants as propolis source in regions where poplar plants are not. Furthermore, we have also identified compounds belongs to coumarins/furocoumarins that have not been previously reported in any propolis sample from Anatolia. Twenty-seven coumarins were found in 28 propolis samples among 64 studied propolis samples from Hakkari. However, only 5 samples contain relatively high percentage of the coumarins, rest of them include coumarins in fairly low quantity.

As conclusion, considering common use of propolis and other bee products throughout of the world they should not allow to sell in the market without safety and toxicity information and full chemical composition data. Further studies, particularly in vivo, are necessary in order to clearly determine the biological activities and allergic constituents of the propolis samples, such as furocoumarins. Thus, bee products, specifically propolis require toxicity and sensitivity and standardization studies.

\section{Acknowledgments}

This study was supported by Scientific Research Projects Unit (Project code: 40525) from Istanbul University.

\section{Supporting Information}

Supporting Information accompanies this paper on http://www.acgpubs.org/RNP

\section{ORCID ID}

Nesrin Ecem Bayram: 0000-0002-5496-8194

Bekir Salih: 0000-0002-8542-6531

Kadriye Sorkun: 0000-0003-3224-7748

Gül Cevahir Öz: 0000-0003-1383-9959 
Gülaçtı Topçu: $\underline{\text { 0000-0002-7946-6545 }}$

\section{References}

[1] V. Bankova (2005). Recent trends and important developments in propolis research, Evid Based Complement Alternat. Med. 2, 29-32.

[2] G. A. Burdock (1998). Review of the biological properties and toxicity of bee propolis (propolis). Food Chem. Toxicol. 36, 347-363.

[3] N. Keskin, S. Hazir, K.H.C. Baser and M. Kürkçüoğlu (2001). Antibacterial activity and chemical composition of Turkish propolis, Z. Naturforsch. C, 56, 1112-1115.

[4] M. Kartal, S. Yıldız, S. Kaya, S. Kurucu and G. Topçu (2003). Antimicrobial activity of propolis samples from two different regions of Anatolia, J. Ethnopharmacol. 86, 69-73.

[5] M.B. Agüero, L. Svetaz, M. Sanchez, L. Luna, B. Lima, M. L. Lopez, S. Zacchino, J. Palermo, D. Wunderlin, G. E. Feresin and A. Tapia (2011). Argentinean Andean propolis associated with the medicinal plant Larrea nitida Cav.(Zygophyllaceae). HPLC-MS and GC-MS characterization and antifungal activity, Food Chem. Toxicol, 49, 1970-1978.

[6] E. L. Ghisalberti (1979). Propolis: A review, Bee World 60, 59-84.

[7] V. Mathivanan, G. N. Shah, M. Manzoor and M. G. Selvisabhanayakam (2013). A review on propolis as a novel folk medicine. Ind. J. Sci. 2, 23-30.

[8] E. Wollenweber, B. M. Hausen and Greenaway W. (1990) Phenolic constituents and sensitizing properties of propolis, poplar balsam and balsam of Peru. Bull. Liaison-Group Polyphen. 15, 112-120.

[9] V Ahuja and A. Ahuja (2011). Apitherapy — a sweet approach to dental diseases. Part II: Propolis, J. Acad. Adv. Dent. Res. 2, 1-8.

[10] V. S. Bankova, S. S. Popov and N. L. Marekov. (1983) A study on flavonoids of propolis, J. Nat. Prod. 46, 471-474.

[11] A. H. Banskota, Y. Tezuka and S. Kadota (2001) Recent progress in pharmacological research of propolis, Phytother. Res. 15, 561-571.

[12] H. Türkez, F. Geyikoğlu, M. I. Yousef, B. Toğar and S. Vançelik (2013). Propolis alleviates 2, 3, 7, 8Tetrachlorodibenzo- $p$-dioxin-induced histological changes, oxidative stress and DNA damage in rat liver, Toxicol. Ind. Health. 29, 677-685.

[13] S. Huang, C. P. Zhang, K. Wang, G. Q. Li and F. L. Hu (2014). Recent advances in the chemical composition of propolis, Molecules 19, 19610-19632.

[14] S. Silici (2008). Investigation of biologically active components in propolis samples from different botanical origin. Erciyes Univ. J. Inst. Sci. Technol. 24, 120-128.

[15] A. Uzel, K. Sorkun, Ö. Önçağ, D. Çoğulu, Ö. Gençay and B. Salih (2005). Chemical compositions and antimicrobial activities of four different Anatolian propolis samples, Microbiol. Res. 160, 189-195.

[16] M. Popova, S. Silici, O. Kaftanoğlu and V. Bankova (2005). Antibacterial activity of Turkish propolis and its qualitative and quantitative chemical composition, Phytomedicine 12, 221-228.

[17] S. Bayram, N. Ecem Bayram, Y. C. Gerçek, G. C. Öz and K. Sorkun (2016). Anticytotoxic and antimutagenic effects of propolis on human Lymphocytes in vitro, Mellifera 16, 38-46.

[18] C. C. Fernandes-Silva, A. Salatino, M. L. F .Salatino, E. D. Breyer and G. Negri (2013). Chemical profiling of six samples of Brazilian propolis, Quim. Nova 36, 237-240.

[19] N. Ecem Bayram, M., Karadayı, M., Güllüce, S., Bayram, K., Sorkun, G. Cevahir Öz, M.N. Aydoğan, T. Y. Koç, B. Alaylar and B. Salih (2015). Genotoxic and antigenotoxic evaluation of propolis by using in vitro bacterial assay systems, Mellifera 15, 29-36.

[20] W. Maciejewicz, M. Daniewski, K. Bal and W. Markowski (2001). GC-MS identification of the flavonoid aglycones isolated from propolis, Chromatographia 53, 343-346.

[21] V. A. Isidorov, L. Szczepaniak and S. Bakier (2014). Rapid GC/MS determination of botanical precursors of Eurasian propolis, Food Chem. 142, 101-106.

[22] S. N. A. Malek, C. W. Phang, H. Ibrahim, N. Abdul Wahab and K. S. Sim (2011). Phytochemical and cytotoxic investigations of Alpinia mutica rhizomes, Molecules 16, 583-589.

[23] M. Paintz and J. Metzner (1979). On the local anaesthetic action of propolis and some of its constituents, Pharmazie 34, 839-841.

[24] M. Sala, M. C. Recio, G. R. Schinella, S. Manez, R. M. Giner, N. M. Cerda and R. J. Luis (2003). Assessment of the anti-inflammatory activity and free radical scavenger activity of tiliroside, Eur. J. Pharmacol. 461, 53-61.

[25] L. Krizkova, M. Nagy, J. Polonyi and L. Ebringer (1998). The effect of flavonoids on ofloxacin-induced mutagenicity in Euglena gracilis, Mutat. Res. 416, 85-92. 
[26] S. Kapoor (2013). Comment on isolation and identification of compounds from Penthorum chinense Pursh with antioxidant and antihepatocarcinoma properties: pinocembrin and its rapidly emerging neuroprotective effects, J. Agr. Food. Chem. 61, 1416.

[27] M. Velikova, V. Bankova, K. Sorkun, S. Houcine, I. Tsvetkova and A. Kujumgiev (2000). Propolis from the Mediterranean region: Chemical composition and antimicrobial activity. Z. Naturforsch. C 55, 790-793.

[28] S. Shalmany, R. Solhnejad, A. Taghvamanesh and N. Masnabadi (2010). Chemical composition of Iran propolis from different regions of Ardebile, J. Sci. I. A. U, 20, 87-92.

[29] K. Boutabet, W. Kebsa, M. Alyane and M. Lahouel (2011). Polyphenolic fraction of Algerian propolis protects rat kidney against acute oxidative stress induced by doxorubicin, Ind. J. Nephrol. 21, 101-106.

[30] V. Seidel, E. Peyfoon, D. G. Watson and J. Fearnley (2008). Comparative study of the antibacterial activity of propolis from different geographical and climatic zones, Phytother. Res. 22, 1256-1263.

[31] F. K. Abd El Hady and A. G. Hegazi (2002). Egyptian Propolis: 2. chemical composition, antiviral and antimicrobial activities of East Nile delta propolis, Z. Naturforsch. 57, 386-94.

[32] M.P. Popova,., V.S. Bankova,., S. Bogdanov, I. Tsvetkova, C. Naydenski, G.L. Marcazzan and A.G. Sabatini (2007). Chemical characteristics of poplar type propolis of different geographic origin, Apidologie 38, 306311.

[33] I. Dimkić, P. Ristivojević, T. Janakiev, T. Berić, J. Trifković, D., Milojković-Opsenica and S. Stanković (2016). Phenolic profiles and antimicrobial activity of various plant resins as potential botanical sources of Serbian propolis, Ind. Crop. Prod. 94, 856-871.

[34] R. Munakata, T. Inoue, T. Koeduka, K. Sasaki, Y. Tsurumaru, A. Sugiyama, Y. Uto, H. Hori, J. Azuma and K. Yazaki (2012). Characterization of coumarin-specific prenyltransferase activities in Citrus limon peel, Biosci. Biotech. Bioch. 76, 1389-1393.

[35] B. Trusheva, I. Todorov, M. Ninova, H. Najdenski, A. Daneshmand and V. Bankova (2010). Antibacterial mono-and sesquiterpene esters of benzoic acids from Iranian propolis, Chem. Centr. J. 4, 8.

[36] C.I. Morikawa, R. Miyaura, T. Kamo, S. Hiradate, J.A. Chavez Perez and Y. Fujii (2011). Aislamiento de la umbeliferona como principal aleloquimico de la planta medicinal peruana Diplostephium foliosissimum (Asteraceae), Rev. Soc. Quím. Perú. 77, 285-291.

[37] G. Autore, S. Marzocco, C. Formisano, M. Bruno, S. Rosselli, M.B. Jemia and F. Senatore (2015). Cytotoxic activity and composition of petroleum ether extract from Magydaris tomentosa (Desf.) W. D. J. Koch (Apiaceae), Molecules 20, 1571-1578.

[38] N. Ecem Bayram, (2015). Determination of botanical origin and chemical composition of propolis samples from Hakkari region. İstanbul University, Institute of Natural and Applied Science Ph.D Thesis, pages: 1239.

[39] I. E. Orhan, F. Tosun and K. Skalicka-Woźniak (2016). Cholinesterase, tyrosinase inhibitory and antioxidant potential of randomly selected Umbelliferous plant species and chromatographic profile of Heracleum platytaenium Boiss. and Angelica sylvestris L. var. sylvestris, J. Serb. Chem. Soc. 81, 357-368.

[40] D. Dincel, S. D. Hatipoğlu, A. C. Gören, and Topçu, G. (2013). Anticholinesterase furocoumarins from Heracleum platytaenium, a species endemic to the Ida Mountains, Turk. J. Chem. 37, 675-683.

[41] J. K. Kim, E. C. Shin, G. G. Park, Y. J. Kim and D. H. Shin (2016). Root extract of water dropwort, Oenanthe javanica (Blume) DC, induces protein and gene expression of phase I carcinogen-metabolizing enzymes in HepG2 cells, SpringerPlus 5, 413.

[42] T. Maruyama, A. Abbaskhan, M. I. Choudhary, Y. Tsuda, Y. Goda, M. Farille and J. P. Reduron (2009). Botanical origin of Indian celery seed (fruit), J. Nat. Med. 63, 248-253.

[43] A. H. Zhao, Y. B. Zhang and X. W. Yang (2016). Simultaneous determination and pharmacokinetics of sixteen Angelicae dahurica coumarins in vivo by LC-ESI-MS/MS following oral delivery in rats, Phytomedicine 23, 1029-1036.

[44] M. Hehmann, R. Lukačin, H. Ekiert and U. Matern (2004). Furanocoumarin biosynthesis in Ammi majus L., Eur. J. Biochem. 271, 932-940.

[45] K. M. Kim, M. J. Kim and J. S. Kang (2009). Absorption, distribution, metabolism, and excretion of decursin and decursinol angelate from Angelica gigas Nakai, .J Microbiol. Biotechnol. 19, 1569-1572.

[46] J. M. Torres-Valencia, O. E. Chávez-Ríos, C. M. Cerda-García-Rojas, E. Burgueño-Tapia and P. JosephNathan (2008). Dihydrofurochromones from Prionosciadium thapsoides, J. Nat. Prod. 71, 1956-1960.

[47] A. I. Buendía-Trujillo, J. M. Torrres-Valencia, P. Joseph-Nathan and E. Burgueño-Tapia (2014). The absolute configuration of angular $3^{\prime}$-acyloxypyranocoumarins by vibrational circular dichroism exciton chirality, Tetrahedron: Asymm. 25, 1418-1423.

[48] M. H. A. Elgamal, N. M. Shalaby, H. Duddeck and M. Hiegemann (1993). Coumarins and coumarin glucosides from the fruits of Ammi majus, Phytochemistry 34, 819-823. 
[49] J. L. Li, L. X. Gao, F. W. Meng, C. L. Tang, R. J. Zhang, J. Y. Li, C. Li , J. Luo and W. M. Zhao, (2015). PTP1B inhibitors from stems of Angelica keiskei (Ashitaba). Bioorg. \& Med. Chem. Letts., 25, 2028-2032.

[50] P. Meier, H. Hotti and H. Rischer (2015). Elicitation of furanocoumarins in poison hemlock (Conium maculatum L.) cell culture, Plant Cell Tissue Organ Cul. (PCTOC), 123, 443-453.

[51] Z. R. Zhang, W. N. Leung, H. Y. Cheung and C. W. Chan (2015). Osthole: A review on its bioactivities, pharmacological properties, and potential as alternative medicine, Evid. Based Complement. Alternat. Med. 1, 1-10.

[52] H. Sbai, I. Saad, N. Ghezal, M. Della Greca and R. Haouala (2016). Bioactive compounds isolated from Petroselinum crispum L. leaves using bioguided fractionation, Ind. Crop. Prod. 89, 207-214.

[53] I. Pfeifer, A. Murauer and M. Ganzera (2016). Determination of coumarins in the roots of Angelica dahurica by supercritical fluid chromatography, J. Pharm. Biomed. Anal. 129, 246-251.

[54] K. Skalicka-Woźniak, T. Mroczek and E. Kozioł (2015). High-performance countercurrent chromatography separation of Peucedanum cervaria fruit extract for the isolation of rare coumarin derivatives, J. Sep. Sci. 38, 179-186.

[55] Razavi, S. M., Nazemiyeh, H., Hajiboland, R., Kumarasamy, Y., Delazar, A., Nahar, L. and Sarker, S. D. (2008). Coumarins from the aerial parts of Prangos uloptera (Apiaceae), Rev. Bras. Farmacogn. 18, 1-5.

[56] A. Abbaskhan, M. I. Choudhary, M. N. Ghayur, Z. Parween, F. Shaheen, A. U. H. Gilani, T. Maruyama, K. Iqbal and Y. Tsuda (2012). Biological activities of Indian celery, Seseli diffusum (Roxb. ex Sm.) Sant. \& Wagh, Phytother. Res. 26, 783-786.

[57] J. S. Jeon, B. H. Um and C. Y. Kim (2017). A new geranyl phenylpropanoid from Heracleum moellendorffii leaves, Chem. Nat. Compd. 53, 56-58.

[58] N. Tabanca, M. Tsikolia, G. Ozek, T. Ozek, A. Abbas, U. R. Bernier, A. Duran, H. C. Başer and I. A. Khan (2016). The identification of suberosin from Prangos pabularia essential oil and its mosquito activity against Aedes aegypti, Rec. Nat. Prod. 10, 311-325.

[59] E. K. Kumatia, K. Annan, R. A. Dickson, A. Y. Mensah, I. K. Amponsah, A. A. Appiah, N.H. Tung, D. A. Edoh and S. Habtemariam (2017). Antiinflammatory and analgesic effects in rodent models of ethanol extract of Clausena anisata roots and their chemical constituents, Nat. Prod. Commun. 12, 67-72.

[60] Y. Bai, D. Li, T. Zhou, N. Qin, Z. Li, Z. Yu and H. Hua (2016). Coumarins from the roots of Angelica dahurica with antioxidant and antiproliferative activities, J. Funct. Foods 20, 453-462.

[61] M. R. Kim, A. A. El-Aty, I. S. Kim and J. H. Shim (2006). Determination of volatile flavor components in danggui cultivars by solvent free injection and hydrodistillation followed by gas chromatographic-mass spectrometric analysis, J. Chromatogr. A. 1116, 259-264.

[62] C. Y. Son, I. H. Baek, G. Y. Song, J. S. Kang and K. I. Kwon (2009). Pharmacological effect of decursin and decursinol angelate from Angelica gigas Nakai, Yakhak Hoeji. 53,303-313.

[63] N. M. Shalaby, H. I. Abd-Alla, H. F. Aly, M. A. Albalawy, K. H. Shaker and J. Bouajila (2014). Preliminary in vitro and in vivo evaluation of antidiabetic activity of Ducrosia anethifolia Boiss. and its linear furanocoumarins, Biomed. Res. Int. 1, 1-13.

[64] G. Innocenti, F. Bourgaud, A. Piovan and D. Favretto (1997). Furocoumarins and other secondary metabolites from Psoralea canescens, Int. J. Pharmacogn. 35, 232-236.

[65] M. Wink (2013). Evolution of secondary metabolites in legumes (Fabaceae), S. Afr. J. Bot. 89, 164-175.

[66] M. Parveen, F. Ahmad, A. M. Malla, M. S. Khan, S. U. Rehman, M. Tabish, M. R. Silva and P. P. Silva (2016). Structure elucidation and DNA binding specificity of natural compounds from Cassia siamea leaves: A biophysical approach, J. Photoch. Photobiol. B. 159, 218-228.

[67] D. Trabelsi, A. Aydi, A. W. Zibetti, G. Della Porta, M. Scognamiglio, V. Cricchio, L. Elisa, A. Manef and A. M. Mainar (2016). Supercritical extraction from Citrus aurantium amara peels using $\mathrm{CO}_{2}$ with ethanol as cosolvent, J. Supercrit. Fluids 117, 33-39.

[68] L. Mukandiwa, J. N. Eloff and V. Naidoo (2015). Larvicidal activity of leaf extracts and seselin from Clausena anisata (Rutaceae) against Aedes aegypti, S. Afr. J. Bot. 100, 169-173.

[69] P. P. Joshi, Y. N. Shukla, D. S. Bhakuni and M. M. Dhar (1975). 6-(2, 3-Dihydroxy-3-methylbutyl)-7methoxycoumarin, a new coumarin from Micromelum pubescens Blume. Ind. J. Chem. 13, 772-774

[70] Tubives, (2017). http://www.tubitak.gov.tr/tubives/

[71] S. Silici (2010). Turkish propolis: Chemical constituents, Mellifera 10, 24-33.

[72] G. Negri, M. C. Marcucci, A. Salatino and M. L. F. Salatino (1998). Hydrocarbons and monoesters of propolis waxes, Apidologie 29, 305-314.

[73] W. Greenaway, T. Scaysbrook and F.R. Whatley (1990). The composition and plant origins of propolis: A report of work at Oxford, Bee World 71, 107-118.

[74] V. Bankova, R. Christov, S. Popov, O. Pureb and G. Bocari (1994) Volatile constituents of propolis, Z. Naturforsch. C 49, 6-10. 
[75] A. Temiz, A. Mumcu, A. Özkök Tüylü, K. Sorkun and B. Salih (2013). Antifungal activity of propolis samples collected from different geographical regions of Turkey against two food-related molds, Aspergillus versicolor and Penicillium aurantiogriseum, The J. Food 38, 135-142.

[76] N. Mercan, I. Kivrak, M. E. Duru, H. Katircioglu, S. Gulcan, S. Malci, G. Acar and B. Salih (2006). Chemical composition effects onto antimicrobial and antioxidant activities of propolis collected from different regions of Turkey, Ann. Microbiol. 56, 373-378.

[77] S. Arslan, S. Silici, D. Percin, A. N. Koç and Ö. Er (2012). Antimicrobial activity of poplar propolis on mutans streptococci and caries development in rats, Turk. J. Biol. 36, 65-73.

[78] K. N. Slessor, M. L. Winston and Y. Le Conte (2005). Pheromone communication in the honeybee (Apis mellifera L.), J. Chem. Ecol. 31, 2731-2745.

[79] N. Duran, M. Muz, G. Culha, G. Duran and B. Ozer (2011). GC-MS analysis and antileishmanial activities of two Turkish propolis types, Parasitol. Res. 108, 95-105.

[80] N. Volpi (2004). Separation of flavonoids and phenolic acids from propolis by capillary zone electrophoresis, Electrophoresis 25, 1872-1878.

[81] N. Sahinler and O. Kaftanoglu (2005). Natural product propolis: Chemical composition, Nat. Prod. Res. 19, $183-188$.

[82] A. Temiz, A. Sener, A. O. Tüylü, K. Sorkun and B. Salih (2011). Antibacterial activity of bee propolis samples from different geographical regions of Turkey against two foodborne pathogens, Salmonella enteritidis and Listeria monocytogenes, Turk. J. Biol. 35, 503-511.

[83] S. Silici and S. Kutluca (2005). Chemical composition and antibacterial activity of propolis collected by three different races of honeybees in the same region, J. Ethnopharmacol. 99, 69-73.

[84] E. Simionatto, J. T. Facco, A. F. Morel, S. R. Giacomelli and C. E. Linares (2012). Chiral analysis of monoterpenes in volatile oils from propolis, J. Chil. Chem. Soc. 57, 1240-1243.

[85] C. Lotti, M. C. Fernandez, A. L. Piccinelli, O. Cuesta-Rubio, I. M. Hernández and L. Rastrelli (2010). Chemical constituents of red Mexican propolis, J. Agr. Food. Chem. 58, 2209-2213.

[86] H. Cheng Z. H. Qin, X. F. Guo, X. S. Hu and J. H. Wu (2013). Geographical origin identification of propolis using GC-MS and electronic nose combined with principal component analysis, Food Res. Int. 51, 813-822.

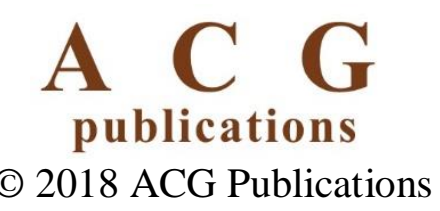

